\title{
EVALUATION OF THE MORISITA INDEX FOR DETERMINATION OF THE SPATIAL DISTRIBUTION OF SPECIES IN A FRAGMENT OF ARAUCARIA FOREST
}

\author{
AMARAL, M.K. ${ }^{1} *$ - PÉLLICO NETTO, S. $^{2}-$ LINGNAU, C. ${ }^{2}-$ FIGUEIREDO FILHO, A. ${ }^{3}$ \\ ${ }^{1}$ Prof. Dr., Department of Mathematics, Federal Technological University of Paraná - Av. Sete \\ de Setembro, 3165, Curitiba, Brazil. 80230-901. (phone: +554133104649 , fax: \\ $+554133104599)$. \\ ${ }^{2}$ Prof. Dr., Department of Forest Sciences, Federal University of Paraná - Av. Lothário \\ Meissner, 632 - Jardim Botânico - Curitiba, Brazil. 80210-170. (phone: +554133604206, fax: \\ +554133604206 ) \\ ${ }^{3}$ Prof. Dr., Department of Engineering Forestry, State University of the Midwest - Campus \\ Irati, PR $153 \mathrm{~km}$ 7, Riozinho, Irati, Brazil. (phone: +554234213000, fax: +554234213067). \\ *Corresponding author \\ e-mail:amaral@utfpr.edu.br \\ (Received $9^{\text {th }}$ Aug 2013; accepted $28^{\text {th }}$ Aug 2014)
}

\begin{abstract}
The Morisita index is widely used to evaluate the spatial distribution patterns of species in a native forest. Thus, by analysing the spatial behaviour of individuals in some special cases, this study obtained and then discussed the critical values for the application of the Morisita index. In the aggregate classification, importance was given to the way the equation was used and on the meaning of the maximum index value. For the uniform distribution, the behaviour of species was presented with one and more than one individual per plot. Additionally, we discussed the values that generated indetermination in the index results, and, in this situation, we suggested the use of the ratio variance/mean as an alternative index for the spatial classification of species distribution. A table was also organized with examples to elucidate the analyses and to lead to a discussion of the reported situations.
\end{abstract}

Keywords: spatial pattern; Morisita index; phytosociological evaluation.

\section{Introduction}

Individuals of the same species in a given geographic area have different spatial patterns of uniformity. The scientific process to generate these patterns is not always simple, but it is important to know and understand the behaviour of the individuals, the population dynamics, the interactions between their peers and the community composition (Ripley, 1981; Diggle, 1983; Bailey and Gatrell, 1995; Haase, 1995; Cressie, 1993; Silva et al., 2008; Rode et al., 2010).

Pielou (1975) has defined diversity as the number of species present in the sample units and has elaborated on the methods to evaluate the variable of each species in a community. He also has stated that diversity depends on the uniformity with which individuals are distributed in the sampling units.

To evaluate the forest diversity, the sample area consisted of 25 permanent plots with an area of 1 ha $(100 \mathrm{~m} \times 100 \mathrm{~m})$ each. We used the quadrat method in the experimental area, and we sought authors who had studied the counting process by the quadrat method. According to Nagai et al. (1985), who studied the quadrat method and defined the number and size per area to be sampled, indicated that 100 quadrats of $0.25 \times 0.25$ 
$\mathrm{m}$ or 40 quadrats of $0.50 \times 0.50 \mathrm{~m}$ were ideal to obtain a determined degree of accuracy in their application.

Reis and Assunção (1998) conducted a study to compare three techniques of sampling the spatial configuration of species and found that the best estimator of performance was the method of counting quadrats because it minimised the variance. In research on spatial patterns, the indices of aggregation or dispersion are determined, and their application is essential for ecological studies or comparisons of sampling methods (Green, 1996).

Morisita (1959 and 1962) proposed an index for an individual's dispersion in a population and described the methodologies to analyse the distribution patterns. Many researchers have applied this index to quantify the degree of spatial dispersion of a species. Morisita's index is characterised as being independent of the population density, but the index is affected by the sample size (Krebs, 1999).

Smith-Gill (1975) proposed an improvement (standardisation) of the index, i.e., he reorganised the calculations such that they could be reported in an absolute scale between -1 to +1 . However, to incorporate this change, a previous calculation of the Morisita index was required.

Additionally, other indices exist that characterise the spatial distribution pattern of individuals, but they will not be discussed in this paper because they will be analysed and reported in other studies.

Moreover, Rossi and Higuchi (1998) evaluated several indexes for detecting the spatial pattern of tree species in the rainforest in Amazonas state and concluded that the ratio variance/mean and the Morisita index were very similar and therefore, adequate for this forest typology.

The ratio variance/mean is simple to calculate and provides for ease of interpretation and evaluation of the statistical significance for the values obtained in relation to the value set for a random pattern. Thus, if the need occurs to use another index in this analysis, the ratio variance/mean will be applied to solve the problems and achieve the desired results.

The application of the index of spatial dispersion to a data set identifies the classification standard of the individual as having an aggregated, random chance or uniform distribution (Ludwig and Reynolds, 1988; Barbosa, 1992; Krebs, 1999; Hay et al., 2000; Silva et al., 2004).

Researchers have defined each one of these patterns with probability and the individual distribution in the sampled area. Thus for the three patterns:

- "The distribution of a given population is said to be random when any of its members have the same probability, at a given time, of occupying any place in space, and when the existence of one or more individuals in a given location does not influence the distribution of the others." (Laroca, 1995, p.109)

- "The regular or uniform dispersion occurs when competition between individuals is strong or when there is positive antagonism that promotes uniform spacing; of course that is also a common pattern in forests and monoculture plantations." (Odum, 2008, p.258)

- "The aggregated dispersion (also called grouped, clumped, contagious or subdispersion) occurs when individuals tend to be attracted (or can survive longer) for particular locations of the environment or when the presence of an individual attracts (or gives rise to) other ."(Begon, et al., 2007, p.165-166) 
Durigan (2012) affirms that the Morisita index suffers from the influences of the size and distribution of the sample units, i.e., a population can present an aggregated distribution at one scale and a random or uniform distribution at another scale. Given this context, this paper aims to analyse the results of the Morisita index by evaluating them with the spatial distribution of individuals in an Araucaria forest fragment. Our objective was to propose a procedure that makes it possible to analyse concomitantly the variations in the outcome of Morisita's index and the format of the spatial distribution of the species.

\section{Material and Methods}

\section{Location and description of the area}

The study area is located on the Parana's second plateau in the municipalities of Teixeira Soares and Fernandes Pinheiro, Paraná state $\left(25^{\circ} 21^{\prime} \mathrm{S}\right.$ and $\left.50^{\circ} 35^{\prime} \mathrm{W}\right)$. According to the Köppen classification, the regional climate is humid subtropical mesothermal $(\mathrm{Cfb})$, characterised by cool summers, frequent and severe frosts and no dry season.

The area belongs to the geological formations of the Palaeozoic groups related to Quaternary deposits, Guatá and Passa Dois. The soil class in the study area is a typical oxisol, alic (Disperati, 2002a; Mazza, 2006).

The experiment encompasses 25 ha divided into 25 blocks of 1 ha each. These were subdivided into four plots of 0.25 ha and additionally crossed by five parallel control strips of $10 \mathrm{~m} \times 50 \mathrm{~m}$ (0.05 ha), to facilitate the spatial mapping of individuals (Figure 1).

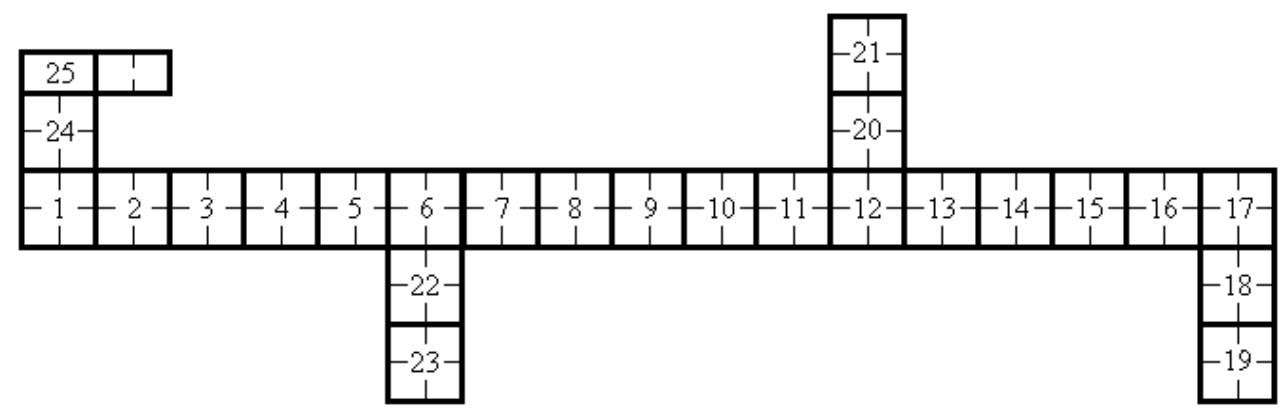

Figure 1. Layout of the blocks (1 ha) and the plots (0.25 ha)

The mapping in 2008 resulted in the location of 14,178 individuals belonging to 118 species of trees and distributed in 43 plant families. The local coordinates $(x, y)$ of each tree species were obtained using the quadrat method.

\section{Analysis of the Spatial Distribution of the Tree Species}

The Morisita index equation has two variables, the total number of plots and the number of individuals per plot (Equation 1). The pattern of spatial arrangement of the tree species is classified by Silveira Neto et al., (1976) as: random, when the Morisita index is equal to one $\left(I_{\delta}=1\right)$; aggregate, when the index is greater than one $\left(I_{\delta}>1\right)$, and uniform or regular and when it is less than one $\left(I_{\delta}<1\right)$. 


$$
I_{\delta}=q\left(\frac{\sum_{i=1}^{q} x^{2}-\sum_{i=1}^{q} x}{\left(\sum_{i=1}^{q} x\right)^{2}-\sum_{i=1}^{q} x}\right)
$$

where:

$I_{\delta}=$ the Morisita index that reveals the dispersion pattern,

$q=$ total number of plots,

$\sum_{i=1}^{q} x=$ sum of the species in each plot, and

$\sum_{i=1}^{q} x^{2}=$ sum of the squares of the number of species in each plot.

The discussion and analysis of the particular cases of the spatial patterns of the species is presented below.

First, the values larger and smaller than one were analysed for the patterns of aggregate and uniform distribution, respectively. According to the classification process, a graph was elaborated to represent them in decreasing order. A species with an aggregate distribution was selected at random to show the calculation of the Morisita index based on a frequency distribution table.

We then investigated the results for the species classified with a random distribution with the Morisita index equal to one. Among the calculated indices, an index value equal to one was not calculated, only those less than or greater to one, except for cases that were indeterminate. Based on these results, all of the cases were analysed, and a Morisita index of one only occurred with species that had zero or one individual in the plot.

The index of the ratio variance/media (Equation 2) solved this problem, as cited by Perry and Mead (1979). The addition of this index was examined, and the index is appropriate, with results similar to the process of classification provided by the Morisita index.

The index of the ratio variance/mean is given by:

$$
I=\frac{s^{2}}{\widehat{m}}
$$

where:

$I=$ index of the ratio variance/mean,

$\widehat{m}=$ sample mean, and

$s^{2}=$ sample variance.

This index is used to measure the deviation of the random arrangements where values equal to unity indicate a random spatial distribution, values less than unity indicate a uniform distribution and values greater than one indicate an aggregated distribution (Rabinovich, 1980).

The index was used to analyse and discuss the situations with species that had one, two or more individuals present in a single plot of the larger experiment.

Finally, a table was constructed with examples of the discussed situations to guide researchers about possible questionable results in the application of Morisita's index. 


\section{Results and Discussion}

The Morisita index was applied to 118 species in the experiment, of which 76 were classified with an aggregate distribution, 24) with a uniform distribution, and 18 with problems in the results were classified as indeterminate. One hundred species were classified with aggregated and uniform distributions, of which ten (five species for each type of distribution) species were randomly selected to represent their type of spatial pattern (Figure 2).

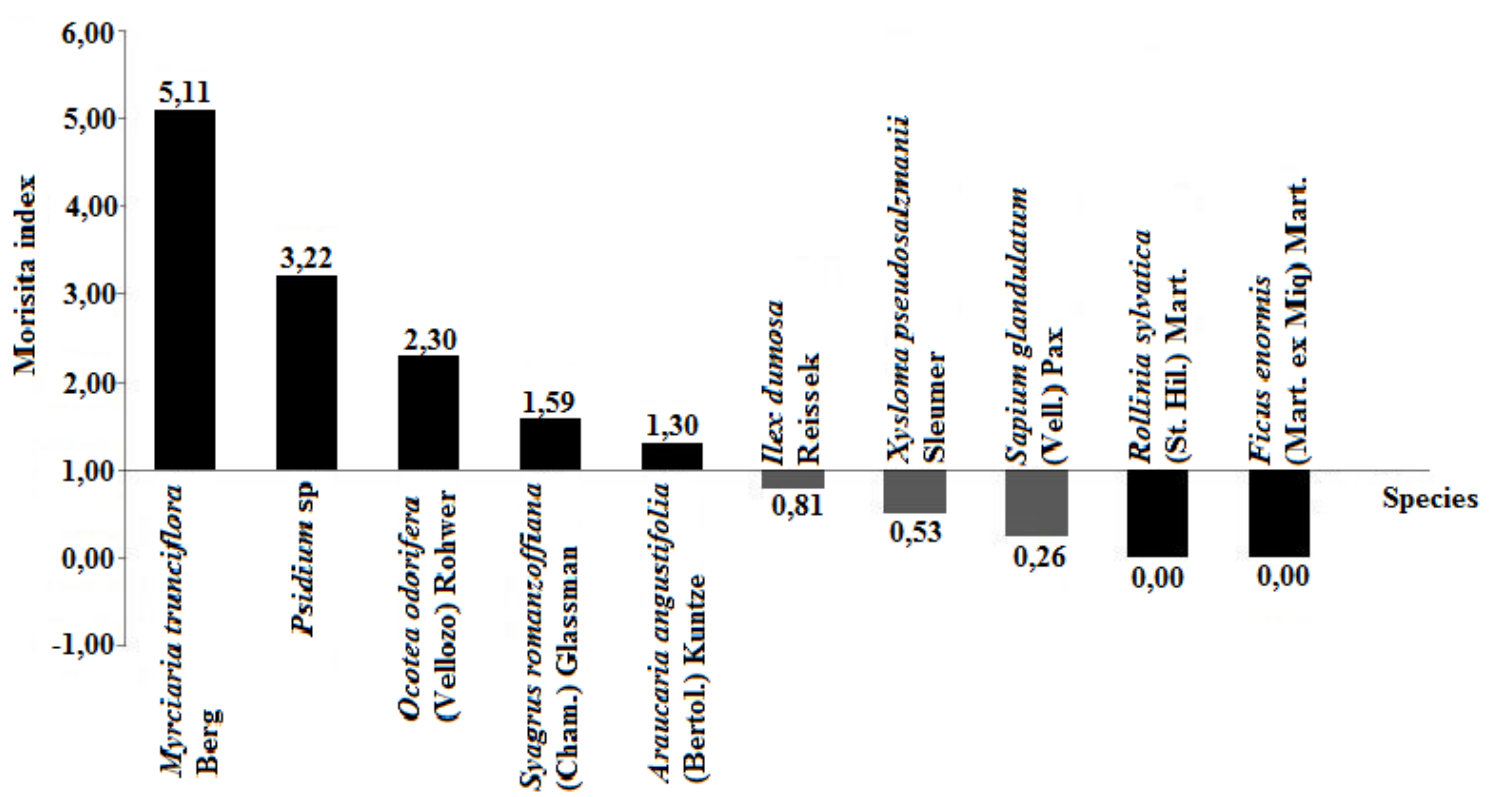

Figure 2. Species with clumped and uniform distributions.

The horizontal axis connects with the coordinate axis at the point $(0,1)$, whereas the ordinate axis represents the Morisita index set by the separation criteria (Figure 2).

Among all species classified in the uniform group, only three resulted in values within the range zero to one because the great majority of the sampling units had only one individual per plot and only a few had species with two or more individuals per plot (Figure 2).

The behaviour of the species with a Morisita index equal to zero, i.e., with a uniform pattern of distribution, indicated that only a single individual was present inside of each experimental plot. For example, the spatial dispersion of Maytenus grandiflora Reissek is presented in Figure 3.

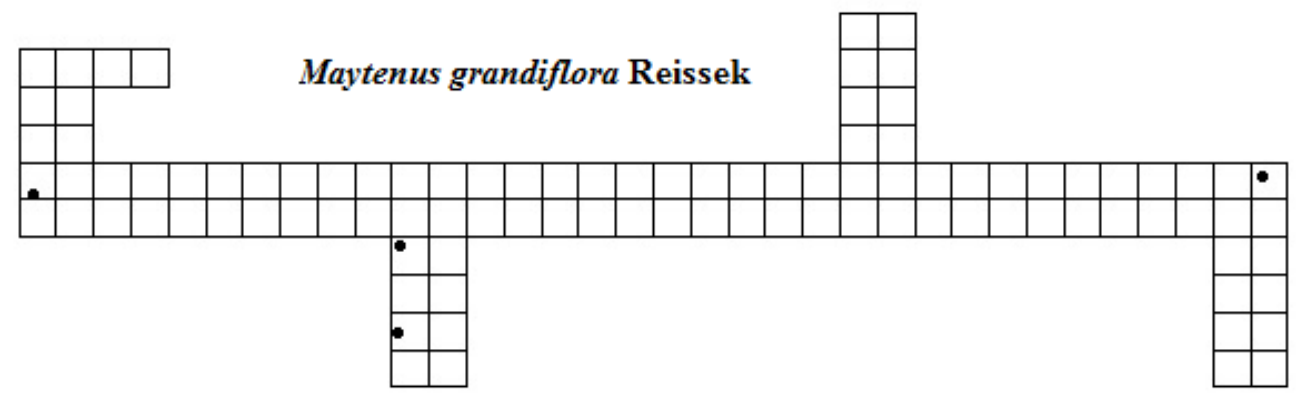

Figure. 3. Location of individuals of the species Maytenus grandiflora Reissek. 
To continue the evaluation of the Morisita indices, Morisita (1959 and 1962) provided a calculation that can explain the meaning of the value (3.22) of the Psidium sp. presented in Figure 2.

When the information is arranged in frequency tables, the calculation replaces individual values with grouped data, as is shown in Table 1.

Table 1. The frequency distribution of Psidium sp.

\begin{tabular}{c|c|c|c|c}
\hline $\begin{array}{c}\text { Number of } \\
\text { individuals }(\boldsymbol{x})\end{array}$ & $\begin{array}{c}\text { Frequency of subplots with } \\
\text { individuals }(\boldsymbol{f})\end{array}$ & $\boldsymbol{f} \boldsymbol{x}$ & $\boldsymbol{x}^{2}$ & $\boldsymbol{f}^{2}$ \\
\hline $\mathbf{0}$ & 82 & 0 & 0 & 0 \\
$\mathbf{1}$ & 8 & 8 & 1 & 8 \\
$\mathbf{2}$ & 8 & 16 & 4 & 32 \\
$\mathbf{3}$ & 2 & 6 & 9 & 18 \\
$\mathbf{4}$ & 0 & 0 & 16 & 0 \\
$\mathbf{5}$ & 0 & 0 & 25 & 0 \\
$\mathbf{6}$ or more & 0 & $\sum \boldsymbol{f} \boldsymbol{x}=\mathbf{3 0}$ & & $\sum \boldsymbol{f} \boldsymbol{x}^{2}=\mathbf{5 8}$ \\
\hline Total & $\boldsymbol{q}=\mathbf{1 0 0}$ & $\mathbf{2}$ & & \\
\hline
\end{tabular}

Source: The author (2013).

The sample calculation is presented in three steps as follows:

$$
\sum_{i=1}^{q} x^{2}-\sum_{i=1}^{q} x=\sum f x^{2}-\sum f x=58-30=28
$$

and

$$
\left(\sum_{i=1}^{q} x\right)^{2}-\sum_{i=1}^{q} x=\left(\sum f x\right)^{2}-\sum f x=(30)^{2}-30=870
$$

and thus,

$$
I_{\delta}=q\left(\frac{\sum_{i=1}^{q} x^{2}-\sum_{i=1}^{q} x}{\left(\sum_{i=1}^{q} x\right)^{2}-\sum_{i=1}^{q} x}\right)=100\left(\frac{28}{870}\right)=3,22
$$

In the calculation of the Morisita index, 18 species in the sampling area presented indeterminacy. For such cases, an equation is presented that is valid for any species that is indeterminate.

As:

$$
q=100
$$


And

$$
\sum_{i=1}^{q} x^{2}=\sum_{i=1}^{q} x=1
$$

Then, equation (1) resulted in indeterminacy:

$$
I_{\delta}=q\left(\frac{\sum_{i=1}^{q} x^{2}-\sum_{i=1}^{q} x}{\left(\sum_{i=1}^{q} x\right)^{2}-\sum_{i=1}^{q} x}\right)=100\left(\frac{1-1}{(1)^{2}-1}\right)=100\left(\frac{0}{0}\right)=\infty
$$

Because of such a situation, the questions were under what other circumstances could this equation generate indeterminacy and what was the proposed solution for a similar occurrence.

First, the possibilities that could lead to indeterminacy in equation (1) were carefully analysed. It was verified that this occurs in only two situations, for zero and one, i.e., zero or only one individual in all of the sample plots of the experiment.

This validation was made by prospecting for all possible values applicable in equation (1), i.e., results equal to zero for both the numerator and denominator of the ratio, as presented in the equations (9) and (10).

$$
\sum_{i=1}^{q} x^{2}-\sum_{i=1}^{q} x=0
$$

and

$$
\left(\sum_{i=1}^{q} x\right)^{2}-\sum_{i=1}^{q} x=0
$$

Consequently,

$$
\sum_{i=1}^{q} x^{2}=\sum_{i=1}^{q} x
$$

and

$$
\left(\sum_{i=1}^{q} x\right)^{2}=\sum_{i=1}^{q} x
$$


Therefore, the only values that satisfy these equalities are zero and one, and the Morisita index is not able to calculate these two particular cases.

Considering the importance of reporting the classification of all identified species in the experiment, it was decided to apply another index that could express appropriately a measure of spatial dispersion. The index ratio variance/mean was selected because of its frequent use by researchers in phytosociological studies. This index has served to compare and validate the results obtained by the application of the Morisita index. The index provided equity when comparing the results of the two indices for all species of the experiment classified with uniform and aggregate distribution patterns. However, for the third group, the index ratio variance/mean presented no indetermination in the results, i.e., the species had a random dispersion pattern. Benício et al. (2010) stated that in this type of distribution individuals are randomly dispersed in a homogeneous environment. Another situation occurred for the species with two or more individuals in a single plot (quadrat) of the experiment. In these cases, the Morisita index will always be equal to the sum of the number of sample plots $\left(I_{\delta}=q\right)$, regardless of the number of individuals in the plots.

This situation is confirmed if we use equal values in the numerator and denominator in Equation 1.

Thus:

$$
\sum_{i=1}^{q} x^{2}-\sum_{i=1}^{q} x=\left(\sum_{i=1}^{q} x\right)^{2}-\sum_{i=1}^{q} x
$$

Consequently,

$$
\sum_{i=1}^{q} x^{2}=\left(\sum_{i=1}^{q} x\right)^{2}
$$

Therefore, this equality is satisfied for $S=\{x \geq 2\}$ individuals distributed in only one plot of the experiment, as is the case for the species Symplocos tetrandra Mart., with a value of 100.00 for the Morisita index (Figure 4).

It is also clear for this particular case that the result of the Morisita index is equal to one, which classifies the species as belonging to the random pattern.

This can be demonstrated by substitutions of the equalities in equation (1), thus:

$$
q=1
$$

and

$$
\sum_{i=1}^{q} x^{2}=\left(\sum_{i=1}^{q} x\right)^{2}
$$


Consequently, the result of Equation 17 is:

$$
I_{\delta}=q\left(\frac{\sum_{i=1}^{q} x^{2}-\sum_{i=1}^{q} x}{\left(\sum_{i=1}^{q} x\right)^{2}-\sum_{i=1}^{q} x}\right)=1
$$

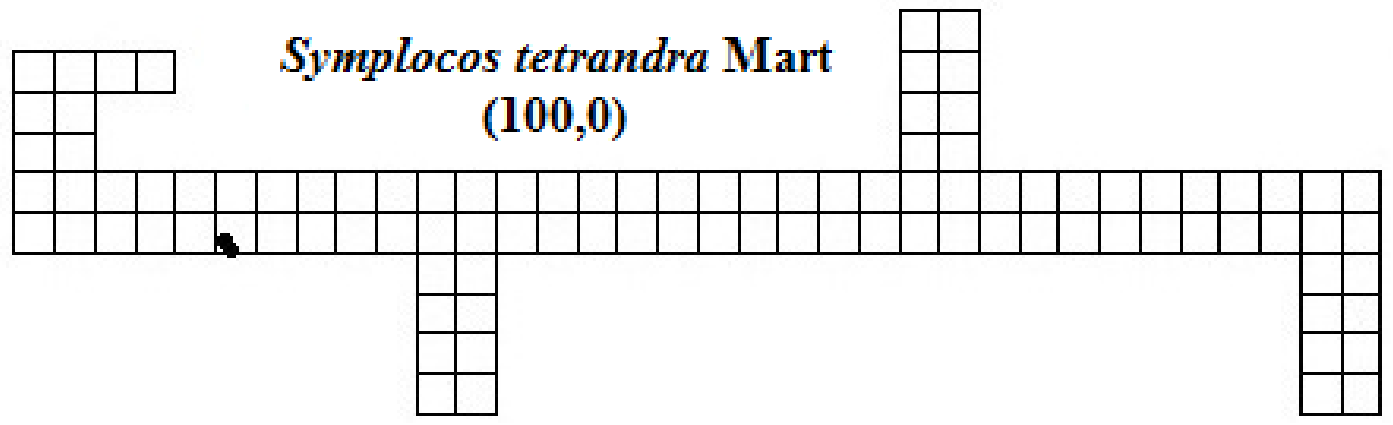

Figure. 4. Location of individuals of the species Symplocos tetrandra Mart.

The limitation of Morisita index is that the index is overly influenced by the amount of quadrats (q) (Bianco, 1984), and it is necessary that for the proper use of the index that the number of quadrats is equal in all areas to be compared (Mesina, 1986). The index is little influenced by the size of the plots and therefore is an excellent indicator of the degree of dispersion (Barros; Machado, 1984).

According to Kanieski et al., (2009), the knowledge of the spatial distribution of a species within the community is an important characteristic for the planning and the management of measures for the conservation of forest formations. Anjos et al., (2004) also confirmed that knowledge about the spatial distribution patterns can provide information on the ecology, support the definition of strategies for management and/or conservation, assist in sampling procedures or simply clarify the spatial structure of a species. Therefore, given the previous results and discussion, Table 2 was constructed with examples that could represent schematically the context of special situations by the application of the Morisita index, excluding the last analysis because it differs with the specified conditions in the area of the experiment, i.e., its division into quadrats.

Table 2. Summary of the results of the Morisita index.

\begin{tabular}{|c|c|c|c|}
\hline Classification & Description & Condition & Examples \\
\hline \multirow{2}{*}{ Aggregate } & $\begin{array}{l}\text { Two or more } \\
\text { individuals in a } \\
\text { single plot }\end{array}$ & $I_{\delta}=q$ & 电 \\
\hline & $\begin{array}{c}\text { Groups of } \\
\text { individuals } \\
\text { concentrated in } \\
\text { plots }\end{array}$ & $1<I_{\sigma}<q$ & 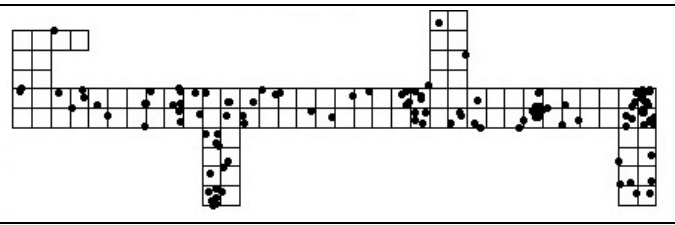 \\
\hline
\end{tabular}




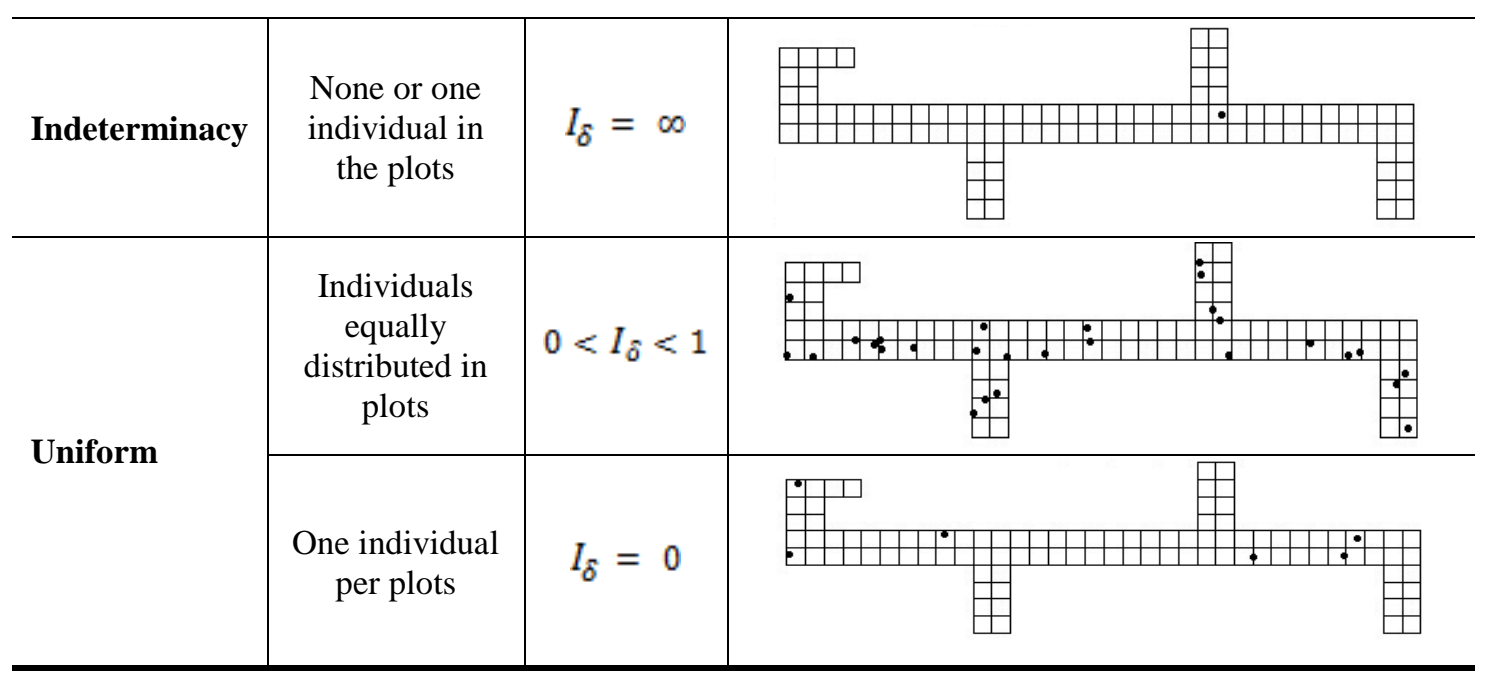

Source: The author (2013).

\section{Conclusions}

The spatial dispersion obtained by implementing the Morisita index resulted in values greater and smaller than one for classifying aggregated and uniforms patterns, respectively.

In the case of uniform distribution, one may have two conditions. The first occurs when only one individual is in each parcel, and, in this case, the Morisita index is equal to zero. In the second, when the index is greater than zero and less than one, many quadrats have only one individual and in the remaining ones there is more than one, but they do not present an aggregated dispersion.

According to the Morisita index and spatial behaviour, the individuals classified with an aggregated distribution pattern are distinguished in three ways. The Morisita index is greater than one, when some subplots feature individuals grouped together in the sampling area. The result is equal to the total number of subplots of the sampling area, when two or more individuals occur in a single subplot. When the number of plots (sampling units) is restricted to one, the Morisita index will be equal to one.

The Morisita index presented indetermination in two cases, when none or only one individual occurred in the experiment. In these situations, its application was inappropriate. In this circumstance, the index ratio variance/mean was selected as an alternative methodology for the classification of the species spatial distribution, which was efficient for detecting this dispersion pattern.

Acknowledgements. To the professors of the State University of Midwest - UNICENTRO, who have established and coordinated the collection of the data in the permanent sample plots in the FLONA of Irati, from where the data used in this study came from.

\section{REFERENCES}

[1] Anjos, A., Mazza, M.C.M., Santos, A.C.M.C., Delfini, L.T. (2004): Análise do padrão de distribuição espacial da araucária (Araucaria angustifolia) em algumas áreas do estado do Paraná, utilizando a função K de Ripley. - Scientia Forestalis 66: 38-45. 
[2] Bailey. T.C., Gatrell, A.C. (1995): Interactive spatial data analysis. Essex: Longman Scientific and Technical, $413 \mathrm{p}$.

[3] Barbosa, J.C. (1992): A amostragem sequencial. In: Fernandes, O.A., Correia, A.C.B., De Bertoli, S.A. (eds.) Manejo integrado de pragas e nematoides. Jaboticabal: FUNEP, 205211.

[4] Barros, P.L.C., Machado, S.do A. (1984): Aplicação de Índices de Dispersão em Espécies de Florestas Tropicais da Amazônia Brasileira. Curitiba: FUPEF, 44p. (Série Cientifica 1).

[5] Begon, N.M., Townsend, C.R., Harper, J. L. (2007): Ecologia: de indivíduos à ecossistemas. 4. ed. Porto Alegre: Artmed, 740 p.

[6] Benício, M.H.M., Pires, G.G., Santos, M.de C.N., Costa, M.do P., Mendes, C.B., Fontes, L., M.A.L. (2010): Estudo da distribuição espacial de Eremanthus erythropappus (DC.) MacLeish em três setores florestais, sob diferentes pressões ambientais, em Lavras, sul de Minas Gerais. ln: XIX Congresso de pós-graduação da UFLA, São Paulo. Anais....Universidade Federal de Lavras: Lavras.

[7] Bianco, R. (1984): Disposicion espacial de Aeneolamia spp (Homoptera: Cercopidae) em zacate pangola (Digitaria decumbens sant). Revista Brasileira de Agrociência 57(1): 95108.

[8] Clapham, A.R. (1936): Over-Dispersion in Grassland Communities and the Use of Statistical Methods in Plant Ecology. - Journal of Ecology 24(1): 232-251.

[9] Cressie, N.A.C. (1993): Statistic for spatial data. New York: Jonh Wiley, 900 p.

[10] Diggle, P.J. (1983): Statistical analysis of spatial point patterns. London: Academic Press, $148 \mathrm{p}$.

[11] Disperati, A.A. (2002): Biodiversidade e sustentabilidade da Floresta Ombrófila Mista na Flona de Irati, PR. Irati: Unicentro. 76p. (Relatório final do projeto do CNPq: Fomento à Pesquisa/ Apoio a Projeto de Pesquisa/Edital CNPq-01/2000-Faixa B).

[12] Durigan, G. (2012): Estrutura e diversidade de comunidades florestais. In: MARTINS, S. V. (Ed.). Ecologia de florestas tropicais do Brasil. Viçosa: Ed.: UFV, 294-325.

[13] Green, R.H. (1996): Measurement of non-randomness in spatial distributions. Researches on Population Ecology, Kyoto 8(1): 1-7.

[14] Haase, P. (1995): Spatial pattern analysis in ecology on Ripley's K-function: introduction and edge correction. Journal of vegetation science 6: 575-582.

[15] Hay, J.D., Bezerril, M.X., Calouro, A.M., Costa, E.M.N., Ferreira, A.A., Gastal, M.L.A., Goes Junior, C.D., Manzan, D.J., Martins, C.R., Monteiro, J.M.G., Oliveira, S.A., Rodrigues, M.C.M., Seyffarth, J.A.S. and Walter, B.M.T. (2000): Comparação do Padrão Espacial em escalas diferentes de espécies nativas do cerrado, em Brasília, DF. - Revista Brasileira de Botânica 23: 341-347.

[16] Kanieski, M.R., Araujo, A.C.B., Gracioli, C.R., Soares, P.R.C., Callegaro, R.M., Longhi, S.J. (2009): Padrão de distribuição da Araucaria angustifolia (Bertol.) Kuntze na Floresta Nacional de São Francisco de Paula, Rio Grande do Sul. AUGM Ambiente.

[17] Krebs, C.J. (1999): Ecological methodology. 2.ed. New York: Benjamin/Cummings, 620 p.

[18] Laroca, S. (1995): Ecologia: princípios e métodos. Petrópolis: Vozes, 197 p.

[19] Ludwig, J.A. and Reynolds, J.F. (1988): Statistical Ecology: a primer on methods and computing. John Wiley and Sons, New York.

[20] Mazza, C.A. da S. (2006): Caracterização ambiental da paisagem da Microrregião Colonial de Irati e zoneamento ambiental da Floresta Nacional de Irati, PR. 147f. Tese (Doutorado em Ecologia e Recursos Naturais) - Centro de Ciências Biológicas e da Saúde, Universidade Federal de São Carlos, São Carlos, SP.

[21] Mesina, R.R.V. (1986): Disposição espacial de Panonychus ulmi (Koch, 1836) (Acarina: Tetranychidae) e determinação do número de amostras na macieira. 88f. Dissertação (Mestrado em Entomologia) - Universidade Federal do Paraná, Curitiba. 
[22] Morisita, M. (1959): Measuring of the Dispersion of Individuals and Analysis of the Distributional Patterns. - Memories of Faculty Science, Kyushu University, Series E. Biology 2: 215-235.

[23] Morisita, M. (1962): Id-index, a Measure of Dispersion of Individuals. - Researches on Population Ecology 4: 1-7.

[24] Nagai, V., Ramiro, Z.A., Panovich, N.V., Hirasawa, M.H. (1985): Método de quadrados: tamanho da amostra em levantamentos de espumas de cigarrinhas-das-pastagens. Bragantia 44(2): 707-713.

[25] Odum, E.P., Barret, G.W. (2008): Fundamentos de ecologia. São Paulo: Thomson Learning, $612 \mathrm{p}$.

[26] Perry, J.N. and Mead, R. (1979): On the power of the index of dispersion test to detect spatial pattern. - Biometrics 35: 613-622.

[27] Pielou, E.C. (1975): Ecological Diversity. Wiley, New York.

[28] Rabinovich, J.E. (1980): Introducion a la ecologia de problaciones animales. Continental, Mexico, 313 p.

[29] Reis, I.A., Assunção, R.M. (1998): Comparando três métodos de amostragem: método de distâncias, contagem de quadrats e conglomerado adaptativo. - Scientia Forestalis 54:119130.

[30] Ripley, B.D. (1981): Spatial statistics. London: John Wiley. 252 p.

[31] Rode, R., Figueiredo Filho, A., Machado, S.A., Galvão, F. (2010): Análise do Padrão Espacial de Espécies e de Grupos Florísticos Estabelecidos em um Povoamento de Araucaria angustifolia e em uma Floresta Ombrófila Mista no Centro-Sul do Paraná. Floresta 40(2): 255-268.

[32] Rossi, L.B.M. and Higuchi, N. (1998): Comparação entre métodos de análise do padrão espacial de oito espécies arbóreas de uma floresta tropical úmida. In: C. Gascon and P. Montinho (eds.). Floresta amazônica: dinâmica, regeneração e manejo 41-59. INPA.

[33] Silva, J.A da., Leite, E.J., Nascimento, A.R.T.; Rezende, J.M de. (2004): Padrão de Distribuição Espacial e Diamétrica de Indivíduos de Aspidosperma spp na Reserva Genética Florestal Tamanduá, DF. Brasília, DF: Embrapa Recursos Genéticos e Biotecnologia, 21p. (Embrapa Recursos Genéticos e Biotecnologia. Comunicado Técnico, 119).

[34] Silva, M.A., Mello, J.M., Scolforo, J.R.S., Czanck Júnior, L., Andrade, I.S., Oliveira, A.D. (2008): Análise da distribuição espacial da candeia (Eremanthus erythropappus (DC.) MacLeish) sujeita ao sistema de manejo porta-sementes. - Cerne 14: 311-316.

[35] Silveira Neto, S., Nakano, O., Barbin, D., Villa Nova, N. (1976): Manual de ecologia dos insetos. Ed.: Ceres, Piracicaba, Brasil. 419 p.

[36] Smith-Gill, S. J. (1975): Cytophysiological basis of disruptive pigmentary patterns in the leopard frog Rana pipiens. II. Wild type and mutant cell specific patterns. - Journal of Morphology 146(1): 35-54. 